\title{
A Supporting Device for Use with Stepwise Thermal
}

\section{Sensors}

GEORGE E. PROBASCO, ARDELL J. BJUGSTAD, AND ROY W. PIERCE

Highlight: A mechanical supporting device is described for use with stepwise thermal sensors. The sensor stand was used for estimating temperatures at various levels below, within, and above the burning fuel.

Temperature of burning vegetation can be estimated using a series of stepwise sensors (Daubenmire, 1968). Measuring temperature at or near soil surfaces is easy, but measuring temperature above the surface requires a supporting device or sensor stand to hold the sensors at the desired sampling levels. The sensor stand described here was developed for use with Thermotubes. ${ }^{1}$ Thermotubes are 4-mm by $60-\mathrm{mm}$, sealed glass tubes containing a segment of heat sensitive paper that changes color, white to black, at predetermined temperatures.

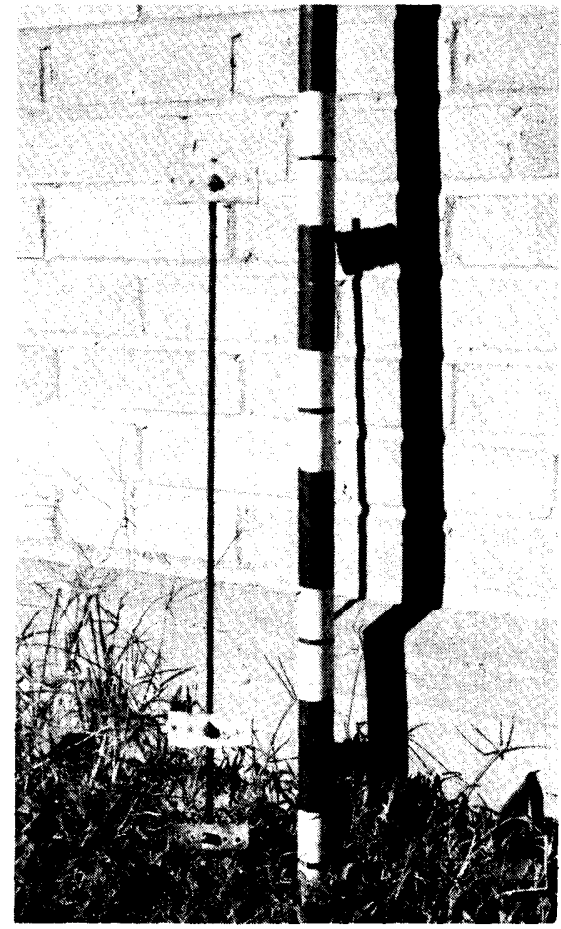

Fig. 1. The assembled sensor stand.

Authors are associate range scientist, North Central Forest Experiment Station, Columbia, Missouri; supervisory range scientist, Rocky Mountain Forest and Range Experiment Station, Rapid City, South Dakota (field office maintained in cooperation with South Dakota School of Mines and Technology); and range technician, Ava Range District, National Forests in Missouri, Ava, Missouri.

Manuscript received September 19, 1975.

${ }^{1}$ Mention of trade name does not constitute endorsement of the product by the U.S. Dep. Agr., Forest Service.

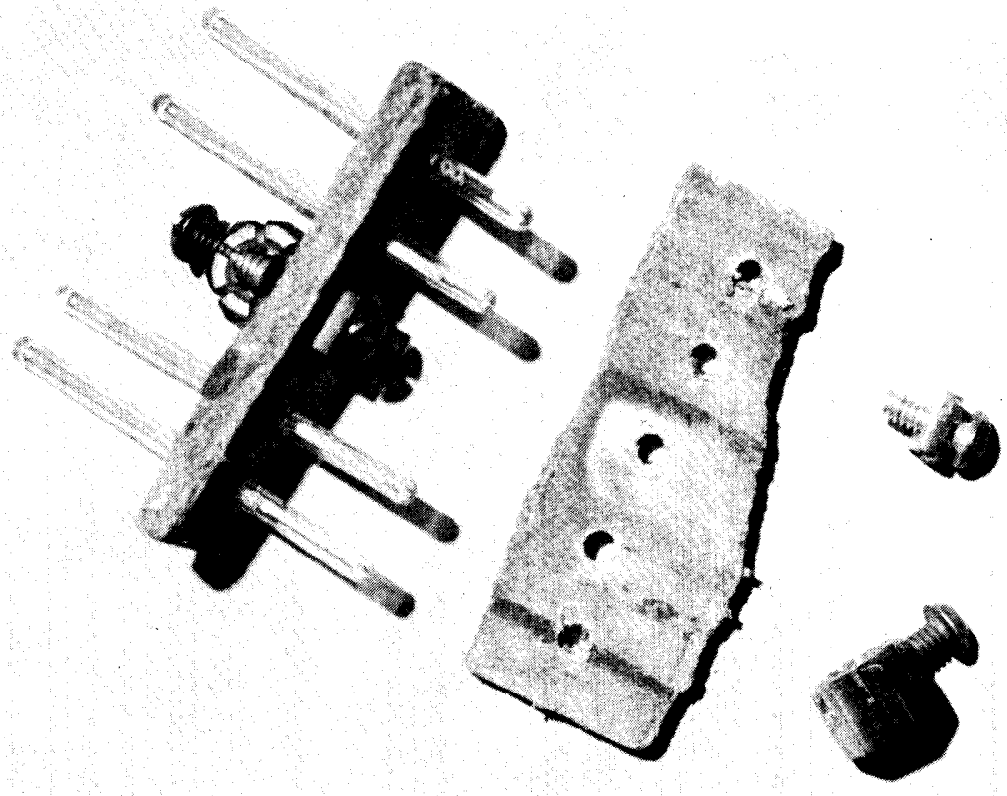

Fig. 2. The asbestos sensor holder and the metal fastener.

Following are instructions for making a sensor stand like the ones we devised for estimating temperatures at various levels below, within, and above a burning fuel. Specifications can be altered, of course, to accommodate different situations.

The stand consists of a supporting rod, an asbestos plate to hold the sensors, and a sliding metal sleeve to attach the plate to the rod (Figs. 1 and 2). Cut support rods $75 \mathrm{~cm}$ long from 5-mm square key stock. Mark the desired levels of sampling by file notches to reduce labor and error when setting them up. Cut the asbestos holders, $2.5 \mathrm{~cm}$ by $7.5 \mathrm{~cm}$, from asbestos board and drill five holes in each one. Mount the plate to the support rod in the center hole and the sensors in the other holes. (We used four sensors because thermotubes do not provide a continuous record of temperature, so it was necessary to use a graded series of tubes and bracket the area of interest.) Make a metal sleeve to fasten the plate to the rod by drilling and threading a $5-\mathrm{mm}$ hole through a machined tap or nut, perpendicular to the existing hole and threads. Fasten the plate at the proper level with a set screw in one side and a screw and lock nut on the other side to maintain the plate in the proper horizontal position (Fig. 2).

Material cost per stand was 49 cents (Table 1). Thermotube prices currently range from 17.5 cents to 12.5 cents per tube. The time required for construction of parts and assembly for one stand was 24 minutes; 2.5 stands per man hour. The sensor stands were assembled in the shop so that field installation involved only setting the units in place and inserting the sensors.

Table 1. Material list and cost data for one sensor stand.

\begin{tabular}{|c|c|c|c|}
\hline Material & $\begin{array}{c}\text { Cost/ } \\
\text { unit }\end{array}$ & $\begin{array}{c}\text { No. of } \\
\text { units }\end{array}$ & $\begin{array}{l}\text { Total } \\
\text { cost }\end{array}$ \\
\hline Key stock & $0.50 / \mathrm{m}$ & 0.61 & 0.31 \\
\hline Asbestos plate & .01 & 3 & .03 \\
\hline $\begin{array}{l}\text { Screw-bolt } \\
\text { and nut }\end{array}$ & .02 & 6 & .12 \\
\hline Metal sleeve & .01 & 3 & .03 \\
\hline Total & & & 0.49 \\
\hline Thermotubes & 0.15 & 12 & 1.80 \\
\hline
\end{tabular}

When pushing the sensor stands into the soil, it was necessary to avoid fuel compaction by the lower plate. This was done by parting the fuel to allow passage of the plate and then returning the fuel to as near the original position as possible. Thermotubes were put into the plates just before burning and the responses were recorded immediately after burning.

\section{Literature Cited}

Daubenmire, R. 1968. Ecology of fire in grasslands. p. 209-267. In: Advances in ecological research. J. B. Cragg (Ed.). Academic Press, Ncw York. 